DOI: https://doi.org/10.47405/mjssh.v6i5.786

\begin{tabular}{|c|c|}
\hline sat & Malaysian Journal of Social Sciences and Humanities (MJSSH) \\
\hline $\begin{array}{l}\text { Malaysian Journal of } \\
\text { Social cciences and }\end{array}$ & Volume 6, Issue 5, May 2021 \\
\hline (MJ-sSH) & e-ISSN : 2504-8562 \\
\hline & $\begin{array}{l}\text { Journal home page: } \\
\text { www.msocialsciences.com }\end{array}$ \\
\hline
\end{tabular}

\title{
Teachers' Role in Teaching Speaking Against the Incongruencies between Curriculum and Curriculum Implementation
}

\author{
Muhammad Azhar Khan bin Ashfar Ahmad1, Azlina Abdul Aziz ${ }^{1}$, Melor Md Yunus ${ }^{1}$ \\ ${ }^{1}$ Fakulti Pendidikan, Universiti Kebangsaan Malaysia (UKM)
}

Correspondence: Muhammad Azhar Khan bin Ashfar Ahmad (cikguazharkhanashfar@gmail.com)

\begin{abstract}
The English language has long been regarded as an important tool in creating a marketable human capital. To be involved with the current, highly competitive economy, a developing country needs to produce a generation of marketable human capital. This is of the utmost importance in achieving economic prosperity. Hence for developing countries like Malaysia, which regarded English as a second language, English is taught in school as a second language. However, the English Proficiency level of the new generation in Malaysia is dwindling and this affected the production of good human capital. Weaknesses that lead to the decline are both systemic and in its implementation as there exist lack of cohesiveness with the curriculum, the implementation and finally with the assessment. In the middle of this are teachers and their struggle in producing students who can use English communicatively. This paper aims to discuss the decline of speaking skills as a result of incongruencies of the curriculum and its implementation and teachers' role in creating marketable human capitals amidst the existence of these incongruencies.
\end{abstract}

Keywords: curriculum, speaking skills, teacher's initiatives

\section{Introduction}

For most learners of the second language, speaking is considered the hardest of the four language skills to be learnt. This is because speaking, unlike reading or writing, happens in real-time which would eliminate the opportunity of editing and revising the speech produced by the learners (Nunan \& Bailey, 2003). In order for a speaker of a language to convey information effectively, they need to have a general proficiency in the components of the language such as pronunciation, vocabulary and grammar (Leong \& Ahmadi, 2017). This could only mean that the objective of teaching and learning speaking skills is very hard to achieve (Mangaleswaran \& Aziz, 2019). Speaking Skill is the most important out of four language skills and mastering it is considered to be the most important aspect in the learning of a second language (Leong \& Ahmadi, 2017; Nunan, 1991). According to Leong and Ahmadi (2017), a learner of a language would evaluate the skills of language acquisition through how well they have improved in speaking ability. This idea is also expressed by Nunan (1991) where he explains that the ability of speaking is almost always the measure of success in second language learning. This shows that the central objective of teaching a language is to give learners the ability to communicate effectively and correctly (Davies \& Pearse, 2000).

As early as 1990s, with the rapid advent of Information and Communication Technology (ICT), it hastened the era of globalisation (Malaysia Education Blueprint, 2013). In 1991, the then fourth Prime 
Minister introduced the Vision 2020 to replace the New Economic Policy in the soul attempt to achieve Economic Prosperity, this is done through the production of marketable human capital in the global scale (Mahmoud \& Mitkees, 2017). The Prime Minister also added at the time of the launch of the Vision 2020 that Education is to lead the movement of the production of the said marketable human capital (Cheong, Hill, \& Leong, 2016). English is seen as a crucial tool to enable a country to compete in the global economy (Lim, Yunus, \& Mohamad, 2016; Moon \& Park, 2019), at the same it is seen as a tool to prepare a generation of human resources to be able to compete in the global economy that at the same time is growing more and more competitive (Ahmad \& Yunus, 2019). Since speaking is seen to be the most important aspect of practising the language (Leong \& Ahmadi, 2017), speaking should be the most important skill to be taught in Malaysian classrooms. While the Malaysian Education System put more weight on the teaching and learning of speaking English in the current Malaysian English Language syllabus, however, there seemed to be no coherence in the production of human capital who can use the language effectively in conversations (Baharun et al., 2016). Which means that while the ability to speak in English is a crucial tool to achieve economic prosperity, and Education is a tool to produce a generation of human capital who can use the language well, there seemed to be no coherence between the aspirations to achieve global economic presence and the production of marketable human capitals.

Malaysian Education Blueprint was introduced in 2013 with the sole objective of producing quality and marketable human capital is appropriate with the need of the very competitive global economy (Malaysia Education Blueprint, 2013). The underlying ethos of the most recent policy, which is the Blueprint, is to accelerate the improvement of labour productivity and to create job opportunities for highly skilled workers (Wan, Sirat, \& Razak, 2018). The recent executive report summary by Education First of the English Proficiency Index (2019) pointed out that the competitive global industry is reported to have employees who are very highly proficient in English. The same report (2019) also pointed out that English Proficiency is an imperative tool for job adaptability, a quality that is sought after and highly marketable for competitive industries. Which means there is no question of the importance of the proficiency level, and to be proficient in the language is to have an adept speaking skill (Leong \& Ahmadi, 2017), in creating a marketable human capital. However, Malaysia has shown a considerable decline in the Education First Proficiency Index from 2011 to 2019. Malaysia was placed at number 9 in 2011 among 44 listed country in the index. Although it is still in the spectrum of high proficiency, however, Malaysia proficiency index has fallen to 26 in 2019 (Education First EPI, 2019). The Malaysian media is quick to bring into attention of this decline as a reason of the failure of Malaysian graduates to find jobs and at the same time call the government for a more constant education policy (Wong, 2019). Hence, this paper aims to discuss on how the incongruencies of the curriculum and its implementation could result into the decline of speaking skills and how teachers could create a marketable human capital despite the existence of these incongruencies. This paper will begin with the description of policy-making processes historically and went on to address the following research questions;

i. How does the teaching of speaking skills is built in the Malaysian education policies?

ii. How does the teaching of speaking skills in Malaysian Education system match the policies?

iii. How does teachers teach speaking skills in the Malaysian Education System?

\section{Literature Review}

\section{Teaching English Against the Backdrop of Education Policies}

To provide context for the role of the teachers in teaching the language of speaking, this paper will address the changes of English Language Education Policies and how it affects teachers. The changes of the Malaysian Education Policy has always affected the process of teaching and learning English as a whole (Rashid, Rahman, \& Yunus, 2017). It was not until the turn of the 1990s that Education Policies were geared towards the production of marketable human capital (Malaysia Education Blueprint, 2013). This stage aptly labelled as the Globalisation Age by Rao (2009), focuses on a competitive approach to make Malaysia as a high-income country by 2020 in line with the 
Government's introduction of the Vision 2020. The constant change in policies has become the background in which teachers teach their students in classrooms, and recent reforms had been focusing on language which gives more pressure towards language teachers as they are the first group people who will be affected by the changes of these reforms (Rashid et al., 2017).

The most controversial of these reforms is the Teaching of English in Math and Science which was introduced in 2003 to prepare Malaysian students for the aggressively competitive global economy (Neill \& Chapman, 2015). This implementation of this particular reform focused on the change of Medium of Instruction in the teaching of Science and Mathematics subjects from Bahasa Melayu to English (Azman, 2016; Rashid et al., 2017). Though this change in policy didn't involve English Teachers, it did however put an expectation and new pressure towards English Teachers to ensure students reach a certain level of mastery in English proficiency in order for the students to use the language in Math and Science classes (Rashid et al., 2017). However, this change of policy brings in controversies which spanned beyond only the pressures towards teachers; the main issue why the Teaching of English in Math and Science was very controversial was because the fear of less proficient student to be left behind (Azman, 2016; Neill \& Chapman, 2015; Rashid et al., 2017). Additionally, the protest towards the implementation of this policy became intense when Malay Nationalist and Chinese Educationist treated this policy as an attack towards the identity of their race (Yang \& Ahmad Ishak, 2012).

The reversal of the same policy was done in 2012 and was also not without controversies, however this shows the complicated relationship Malaysia has with English as a language. This reversal of the Teaching of English in Math and Science is a perfect example of how English Language is viewed as a threat to the Malaysian Identity and also the Malay Language, since the major aims of the opposing groups that calls for the abolishment of the policy is to uphold the Malay Language and the Malaysian Identity as the policy is perceived to be a tool in eroding the sovereignty of the Malay Language and Malaysian Identity (Cheong et al., 2016). This shows the complicated relationship between the National Language and also English where Malaysia have to accommodate the needs to be globally relevant by commodifying English Language Proficiency while at the same time maintaining and preserving investments towards the Malay Language as the identity of the Malaysian citizen (Albury $\&$ Khin, 2016). These two ideas seemed to be mutually exclusive as the teaching and learning of both languages seemed to be always a threat to each other.

However, with the reversal of the Teaching of English in Math and Science, it heralded the arrival of another policy which is Memartabatkan Bahasa Melayu dan Memperkasakan Bahasa Inggeris (MBMMBI) directly translated as Upholding the Malay Language and Strengthening the Command of English. With the implementation of this policy, the medium of instruction for Math and Science subjects was reverted back to the National Language (Azman, 2016; Majid et al., 2012; Neill \& Chapman, 2015; Rashid et al., 2017). The MBMMBI Policy looks to uphold the Malay language not only as the medium of instruction but also as the language of knowledge that is able to produce its own body of work (The Roadmap, 2015). Also, this policy is geared in strengthening the proficiency of the Malaysian students in their command of English through English Language programs and the Teaching and Learning of English in schools (The Roadmap, 2015).

This complicated situation would often serve as a stumbling block for the teaching and learning of English as a Second Language, the rapid and constant change of the policies would hinder teachers from becoming effective educators. According to Rashid et al. (2017), teachers lack support and guidance in order for them to fully comprehend and cope with the constant changes of the policies and also to professionally develop themselves to keep up with the changes. It is understood that for a policy to realise its full potential and effects on the students, it depends a lot on teachers who are teaching in schools (Majid et al., 2012). Hence it is understandable that in the midst of policy changes, the production of marketable, competitive human capitals seemed to maintain as aspirations rather than a successful achievement. 


\section{Speaking Curriculum in the Teaching of English as a Second Language in Malaysia}

\section{Common European Framework Reference (CEFR)}

The Common European Framework Reference (CEFR) was introduced in Malaysia to equip students with the language that they will use in their daily lives (Adila, Samat, Muthu, \& Yunus, 2019). This standard-based English language curriculum aims to provide students with the ability to communicate confidently, proficiently and competently (KSSM, 2017). CEFR is the latest method that is embedded into the new curriculum in the hope of producing a more holistic individual or a marketable human capital (Azman, 2016). In the new curriculum, the allocation of learning objectives for the four language skills seemed to be equally important as the standard-based English language curriculum comes with a form of assessment that measure all four skills in the School-Based Assessment system (Azman, 2016; The Roadmap, 2015, KSSM, 2017; Rashid et al., 2017). The CEFR has just started to be implemented in 2017 along with the advent of the new syllabus. Philosophically it has the appropriate ethos in producing a generation of proficient English language users, however, the impact of the new curriculum is yet to be seen as the first set of students who started the experience will only sit for the Malaysian Certificate of Education, or Sijil Pelajaran Malaysia in 2021. However, we need to also bear in mind that the change of the previous curriculum towards the new curriculum requires a major overhaul of the teachers' approach of teaching in school, hence in the time of its implementation, Mohamad Uri \& Abd Aziz (2018), has already outlined major obstacles in implementing CEFR in Malaysian Schools;

i. Even though the Teachers are optimistic with the CEFR implementation in producing students who are proficient in English, teacher lack knowledge of how to really implement the CEFR in their classrooms, this is in line with Rashid et al. (2017), in his findings, the lack of training and professional development among teachers seemed wanting in implementing any educational policies in school.

ii. The lack of CEFR experts in Malaysia to produce a more localised textbooks to be used with the implementation of the CEFR in Malaysia brought with it more problems as the current textbooks used are imported textbooks with imported context. As has been pointed out Leong $\&$ Ahmadi (2017), a conducive environment for students to learn speaking is imperative and more localised materials are needed in creating a proper conducive learning environment (Ahmad \& Yunus, 2019; Chan, Yunus, \& Mohamad, 2017). This also surprisingly coincided against the Roadmap in which the Roadmap suggests a more localised context to enable students to embrace the language as they are learning it (The Roadmap, 2015).

It is no doubt that the adoption of CEFR in Malaysian Curriculum is necessary, however, a more comprehensive guide and a longer time is needed for the phasing in and out of the Education System in order teachers could understand and implement with confidence (Mohamad Uri \& Abd Aziz, 2018). This adoption of a new model also adds to teachers' workload that would usually serve as a distraction from the actual process of teaching and learning of English. This had been explained by Rashid et al. (2017), which noted that the implementation of a new policy without proper training for teachers would result on a heavy workload that serves as distraction to teaching and learning English.

\section{The Integrated English Language Curriculum (KBSM) and Speaking Skills}

Students who are studying in tertiary level are expected to have good proficiency in English. There are certain requirements in tertiary level that requires students to have a good communicative skill and speaking skill in English (Baharun et al., 2016). Even with the new curriculum, the Standard-based English Language Curriculum has set a target where students who graduated secondary school would be expected to have a B1 level of proficiency based on the framework (KSSM, 2017). This is to mean the students would be an independent user of English and would be able to interact spontaneously with a degree of fluency, students who are in this level are also able to hold a conversation with a native English speaker without strain from both parties (University of Cambridge, 2011). 
The Integrated English Language Curriculum or in malay Kurikulum Bersepadu Sekolah Menengah (KBSM) is the current curriculum that is still used in Secondary school only at the form 5 level in 2020 as the CEFR and the new Standard-Based English Language Curriculum has taken into effect since 2017 and will fully replace KBSM in 2021. This curriculum had been implemented and used in school since 1982 (Azman, 2016). At the time of its conception and first implementation, KBSM is viewed to be a dynamic approach to teach English in the aim enabling students to use the language communicatively (Azman, 1994). The curriculum would later be reviewed and republished in 2003 and that is the curriculum used by students up to year 2020. Interestingly even with the review of the curriculum, the purpose and the aims of the English Language Teaching in Malaysia remained to teach students communicative skills that will help them in social interactions (Curriculum Development Center, 2003).

The ethos of the curriculum seemed to be perfect in producing a generation of human capital with the ability to use English communicatively, however, there seemed to be no coherence with the curriculum and the product of the Integrated English Language Curriculum; students in the tertiary level seemed to encounter difficulties and anxiety when they have to communicate in the English Language (Hashim, Yunus, \& Hashim, 2018). Tertiary education in Malaysia mostly uses English as medium of instruction, however, not only that it is used as medium of instruction, it is also used for oral assessment through presentations and for this, an academic-based proficiency is a necessity (Baharun et al., 2016). An outlook towards the results of the Malaysian University Entrance Test would paint a clearer picture to this lack of cohesiveness between school-based curriculum and the intended product aspired by the curriculum. Based on the Malaysian University Entrance Test 2017 annual report by Majlis Peperiksaan Malaysia (2017), only $0.12 \%$ of candidates who sat for the test in 2017 managed to achieve Band 6, which is the highest band for the test. A staggering $68.28 \%$ of the candidates accumulate Band 1-3, which could only mean that these $68.28 \%$ aspired university students are from the spectrum of very limited to modest users. The candidates in the lower spectrum are reported to be lacking in confidence and prone to hesitancies in their speech, these groups of candidates also committed severe grammatical errors which would hamper intelligibility of their speech and they are reported to be unable to string sentences and sustain the conversation according to the prompt given (Majlis Peperiksaan Malaysia, 2017).

The deficit of the speaking skills at the university level could be traced back towards the secondary school curriculum which at this time is still using the Integrated English Language Curriculum (Baharun et al., 2016). However, a more through look into the Integrated English Language Curriculum would reveal that the curriculum that was used since 2003 is communication-based (Azman, 2016; Baharun et al., 2016). As had been discussed earlier, the aim of the Integrated English Language Curriculum is to enable students to be communicatively adept during social interactions in English (Curriculum Development Center, 2003). Baharun et al. (2016) in their analysis of the Form Five English Language Textbook and Form Five English Language Curriculum Specifications that is used within the KBSM since 2003 showed that the Form Five documents used for Teaching and Learning of English is communicative in nature and reflects the approach of Communicative Language Teaching. So it shows that the problem which contributes to the low proficient English users in university is not caused by the curriculum adopted in the Malaysian Education System (Baharun et al., 2016).

\section{Examination-Oriented Approach and the Hindrance to the Teaching of Speaking Skills}

Admittedly, while the four skills are thought in schools, the gravity of teaching the language of Speaking and Listening are less compared to Reading and Writing (Kandasamy \& Habil, 2018). Malaysian Public Standardized Assessments such as Malaysia Certificate of Education or Sijil Pelajaran Malaysia are catered to or/and more focussed on Reading and Writing (Idris \& Zakaria, 2016; Zaki, Yunus, \& Hashim, 2017). Noting that language testing would often dictate what needs to be taught (Roever \& McNamara, 2006), obviously the gravity of teaching and learning will be heavier on only Reading and Writing skills. The idea that examinations are not focussed on speaking skills 
hinder the teachers' focus from teaching speaking in school and would give more attention to the teaching and learning of reading and writing skills. This would encumber the development of students' speaking skills, since it is established that speaking skill is a skill flourished by practice (Lucanus, 2017). Lucanus (2017), added that students' participation in real or mock presentation and speechbased activities will help students to master the art of oral communication, not only that, it also helps in eliminating other impediments to speaking such as anxiety and the lack of confidence.

The Malaysian Standardized Assessment in KBSM only assess speaking skills during the SchoolBased Oral Assessment that is done quarterly during the two-year period after reaching the upper forms (Ministry Of Education, 2002). However, the School-Based Oral Assessment is only based in school and administered by teachers in school. Just like the teaching of Speaking and Listening skills, it is not given proper attention that it deserves by students in school maybe because they see little relevancies in School-Based Oral Assessment in determining their future, since standardised examinations play a bigger role in setting the course of their future (Rahman, 2016). Furthermore, a heavier cognitive process is required to accurately assess oral proficiency in school (Idris \& Zakaria, 2016). In order to assess communication skills, assessors would have to first listen and comprehend, then assessors are expected to analyse the candidates' performances by matching them with assessment criteria and finally giving them the appropriate marks and bands. All these happens simultaneously and in real time (Idris \& Zakaria, 2016). This assessment requires undivided attention and a long time to finish and could be taxing for the assessors, who in this case are teachers to administer the assessment (Rashid et al., 2017). This shows that while both curriculums entail Communicative Language Teaching, the requirement of the standardised exams could be an influencing factor which urge teachers to focus more on reading and writing in the teaching and learning of English in schools and give less attention on the teaching and learning of Speaking skills, as language tests often became a deciding factor for what needs to be taught in school (Roever \& McNamara, 2006).

\section{Teacher's role in Teaching the Language of Speaking in Malaysia}

\section{The Relationship of Malaysian English Curriculum and the Ideal Characteristics of an English Teacher}

Davies and Pearse (2000), in their book 'Success in English Teaching' have already outlined certain characteristics that all language teachers have in common;

i. English Teachers have knowledge that goes beyond grammar rules, they should have practical command of English.

ii. English Teachers use English most of the time in every class, including the beginners' class.

iii. English Teachers think in terms of learners' practise, not teachers' explanations.

iv. English Teachers will find time for real communicative activities, not just the practise of language forms.

v. English Teachers will focus on learners' needs and not just engrossed in completing the syllabus or textbook.

The five characteristics of an English Teacher echoes the approaches suggested in Malaysian Curriculum introduced by the constant change of policies. Learner-Centeredness in teaching language especially in the teaching of speaking skills is strongly suggested in both KBSM and KSSM (Curriculum Development Center, 2003; Malaysia Education Blueprint, 2013; The Roadmap, 2015; KSSM 2017). In the Curriculum Specifications under the KBSM, Learner-Centeredness is outlined as one of the items teachers need to consider while planning the lesson in class. At the same time, Thinking Skills and Multiple Intelligences are also listed under the Educational Emphasis Section (Curriculum Development Center, 2003). This shows that the KBSM had already outlined LearnerCenteredness which is in-line with the teachers' characteristics that is shown by Davies \& Pearse (2000). In the list of characteristics, English Teachers are those who care more about what the students need than how the curriculum needs to be completed, hence the KBSM is a curriculum that entails the 
same philosophy as it urges teachers to think of the learners' needs more by listing the educational emphasis and considerations in the curriculum.

The KSSM presents more clarity in its parallelism with the teachers' characteristics while at the same time still holds the learner-centeredness spirit similar to its predecessor, the KBSM. The principals of the Standard-Based English Education Curriculum is very much learner-centred and relevant to the requirements in preparing students in becoming marketable human capital (Malaysia Education Blueprint, 2013; The Roadmap 2015). The Curriculum aims to prepare students for real world's situations, help students acquire global competencies and develop students to become confident and competent communicators (KSSM, 2017, 2018). According to the 2018 Standard-Based document (2018) that will be used for the form 4 students in 2020, teachers are suggested to use teaching and learning strategies that involves cognitive and metacognitive process, which will also accommodate different learning styles; the strategies are Inquiry-Based Learning, Student-Centeredness, ProblemBased Learning and Cooperative Learning (KSSM, 2018). These teaching and Learning strategies promotes $21^{\text {st }}$ Century Skills and student-centeredness. More teaching and learning strategies such as flipped-classroom or Collaborative Learning are suggested through the Roadmap (The Roadmap, 2015). All recommendations on teaching and learning strategies and the principals that underpinned the curriculum documents in Malaysia reverberate the five teachers' characteristics as listed by Davies $\&$ Pearse (2000). This means that the curriculum calls for a more than just an examination-oriented approach by teachers.

\section{Teachers' Initiatives and Teaching Innovations in Improving Speaking Skills}

Among other factors, social constructs such as learners' anxiety and inhibitions proved to be the most common factor which obstruct and jeopardise the teaching and learning of speaking skills which will further cause learners to not be proficient in speaking in English. Some studies (e.g., Adila et al., 2019; Ansari, 2015; M. R. Khan, Khan, \& Ahmad, 2016; S. M. Khan, 2015; Leong \& Ahmadi, 2017; Nguyen \& Tran, 2015; Toyama \& Mori, 2017) have supported this conclusion. Leong \& Ahmadi (2017) noted that second language learners often perceived that having to speak English is to welcome criticism, thus it causes learners to stay silent rather than attempt to speak in lessons. As Lucanus (2017) has already pointed out that speaking is a skill that is honed with practise, so the fear of criticism, which creates inhibitions and causes anxiety, will prove to be a significant detriment towards achieving speaking proficiency in the second language.

In solving these problems, teachers' role is imperative. As had been discussed by Ansari (2015), teachers hold a primary role in reducing anxiety and inhibitions. This will take effect while teachers are organising and conducting a task and also evaluating students' performance. Apart from teachers' manner in teaching speaking in school, Ansari (2015) found that teachers' choice of activities could greatly influence the reduction of anxiety levels among students as students. This resonates the principals presented by both curriculum currently adopted in Malaysia (e.g.,Curriculum Development Center, 2003; KSSM, 2018). This idea is supported by Misbah, Mohamad, Yunus, \& Ya'acob (2017), in their study, they have pointed that teachers should take a pertinent role in determining activities which could improve students' vocabulary, which will in turn improve the students' speaking skills. Misbah et al. (2017) also pointed out that to reduce inhibitions, there is an importance of having a conducive and a supportive learning environment in aiding the teaching and learning English. The idea of learning environment is also explored by Ansari (2015) where he pointed out that the creation of a stress-free learning environment, teeming with speaking opportunities is imperative in the teaching and learning of speaking effectively. He added that the responsibility of creating such environment falls on the teachers who are teaching in schools.

The creation of speaking opportunities and conducive environment have been proven to be working in other studies. Group discussion or group work exercises is a very good way in facilitating communication (M. R. Khan et al., 2016). The existence of group discussion carried out in an action research study done by Chan et al. (2017) improved the speaking skills of the subjects of the research. Chan observed that students' confidence level improved with the existence of safe and friendly learning environment. This greatly echoes the idea of creating a conducive environment that will 
accommodate and further enhance the teaching and learning of speaking skills presented by Misbah et al. (2017) and Ansari (2015). Another study that shows the existence of conducive environment is effective in teaching and learning of speaking is done by Ahmad \& Yunus (2019) where the subjects involved in this study improved in speaking test scores after a collaborative learning approach was done in teaching English in school. This is in line with the suggestions by Leong \& Ahmadi (2017), they pointed out that teachers are responsible in creating opportunities for students to speak through speaking activities.

The adoption of the teaching and learning strategies doled out by the curriculum documents in Malaysian schools turned out to have positive results with the improvements of students' speaking skills. This was explained by Ismail (2018) in an article written for the Malaysian Teachers' Magazine, 'Pendidik' in 2018. According to Ismail (2018), teachers will find teaching and learning success if the Six Students' Aspirations outlined by the Malaysian Education Blueprint (2013-2025) is implemented in classrooms. Among the four teachers featured in the article, three of them teaches English in preschool, primary and secondary school respectively. All three teachers find that by implementing the aspirations from the Malaysian Education Blueprint, it helps them to innovate and always think of a better way to teach their students in school (Ismail, 2018). This strengthen the idea that teachers play a huge role in the teaching and learning of speaking. This is in line with yet another action research study which findings supported the same conclusion; Adila et al. (2019) found that a creative teaching approach done in classroom managed to improve the speaking skills of the subjects involved. She went to further conclude that English Teachers need to be responsible in thinking of innovative and engaging ways to increase students' motivation and to mediate engagement between students and the teaching and learning of speaking skills.

A study done among Learners of English as a Second Language in Saudi Arabia also showed the utmost importance of the role of language instructors or teachers in facilitating an effective teaching and learning of speaking skills (S. M. Khan, 2015). This point of view is also shared by Leong \& Ahmadi (2017), they noted that teachers need to choose the best teaching method after they understood students' interests and feelings. Knowing students is highly imperative in the teaching and learning of speaking. This concept underpins another action research study done by Hashim et al. (2018) where she applies Mobile Assisted Language Learning (MALL) in the teaching of communication skills, she found that it is highly effective in eliminating anxiety and inhibitions among learners of the second language and accentuate the learning of Speaking Skills. She also discussed the importance of teachers taking the time to get to know the needs of each students when teaching the communication skills or speaking skills. It is imperative to get to know students since it will influence the method that teachers will use in teaching speaking in classrooms (Hashim et al., 2018; S. M. Khan, 2015; Leong \& Ahmadi, 2017).

These practise of innovating and creative teaching done by teachers in Malaysia is creating solutions in the teaching and learning of speaking skills. It eliminates the problem of anxiety and inhibitions while at the same time create opportunities and conducive environment for learners to practise the speaking skills they are trying to acquire. It is interesting to note that these practise of innovation in the teaching and learning greatly resembles the teachers characteristics outlines by Davies \& Pearse (2000), which means this is a very good practice in teaching the speaking skills to students, as has been portrayed by the success in teaching speaking skills through innovation and creative teaching done in other studies, (e.g., Kandasamy \& Habil, 2018; Mangaleswaran \& Aziz, 2019; Moon \& Park, 2019; Ramamuruthy, 2019; Toyama \& Mori, 2017; Zaki et al., 2017) . It is also interesting to note that the approaches that is adopted by these innovative teachers echoes the approaches encouraged by the English curriculum used in Malaysia, both the KSSM and KBSM (Ismail, 2018).

\section{Discussion}

This paper discussed the evolution of the Malaysian Education Policy since the beginning of 1990s with the introduction of the vision 2020. The country's education policy had a new purpose and that is to build a marketable human capital and as the years grows closer to the year 2020, the need to have a 
marketable human capital became more and more important as the world are shrinking in this globalisation age (Mahmoud \& Mitkees, 2017). This paper also discussed the pressure this new goal has towards the working teachers in school who have to teach English against the backdrop of ever changing policies, the lack of training and familiarity towards each of the new policies would result into ineffective teaching and learning of English as a second language (Rashid et al., 2017). This could be shown through the resistance teachers gave towards the implementation of CEFR in Malaysia even when teachers admits that it is actually good for the students English proficiency (Mohamad Uri \& Abd Aziz, 2018). This paper points out the importance of communicating in English as a tool to be a part of the fast-paced and the shrinking world of the globalisation age, and to achieve economic prosperity (Moon \& Park, 2019; Thirusanku \& Yunus, 2017). This is also an idea that is discussed extensively in the most recent educational policy documents such as Malaysia Education Blueprint (2013) and The English Roadmap (2015).

The country's demands in the Education System to produce human capitals who are globally marketable is not without providing tools for the teachers to use. The curriculum is teeming with communication elements to achieve that end. The integrated English curriculum are communicative in nature as it adopt the Communicative Language Teaching (Baharun et al., 2016). While the new KSSM with its English framework adopting the Common European Framework of Reference promotes speaking skills equally with other skills (KSSM, 2018). At the same time both curricula suggest innovative and creative learning strategies, along with $21^{\text {st }}$ century learning strategies better suited with the aims to produce marketable human capital. However, teachers are often too bogged down by workload to really implement these strategies while teaching (Rashid et al., 2017). It is also important to note that standard examinations in Malaysia tests only on Reading and Writing skills, and speaking skills are only tested during school-based assessments. Noting that language tests dictates the teaching and learning of the language (Roever \& McNamara, 2006), the teaching of speaking further slipped out of teachers' priority to be taught in schools.

This may have resulted into the diminishing speaking skills experienced by the new generations of Malaysians, this paper explained the poor speaking skill results of Malaysian University Entrance Test for the year of 2017 where $68.28 \%$ of candidates scored in the spectrum of limited to moderate users of the language (Majlis Peperiksaan Malaysia, 2017). The English Proficiency Index report further puts the Malaysian Speaking skill into a more precarious situation. The country had been slipping in the index since 2011 where Malaysia placed $9^{\text {th }}$ out of 44 countries and now Malaysia is placed 26 in the 100 countries studied by the proficiency index (Education First EPI, 2019). The media (see Wong, 2019) had been quick to point this as a reason why the graduates in this country find it hard to excel in the job markets let alone in the global market. Hence, even though the Malaysian Education Policy has provided the guideline and the tools for teachers to teach the language of speaking in order to supply the country with abled human capitals to achieve economic prominence, the venture is often bogged down with teachers' workload and also the existence of examination system which does not really test all four skills equally. Teachers play a huge role in this since their understanding towards the matters of the policy would eventually determine the success of the policies (Majid et al., 2012), failure to understand would often result with teachers perceiving the policies as additional, if not tedious, workload (Yaakob, Musa, Habibi, \& Othman, 2019). Hence teachers play the most crucial role in balancing the incongruencies between the curriculum and how it is implemented in school.

\section{Conclusion}

While it is agreed that speaking skill is important to build communication skills, which will in turn become a vital tool in developing marketable human capital in the competitive global economy, the teaching and learning of speaking skills continued to be side-lined in Malaysian schools. This has given rise to the proficiency problems as had been described by the Malaysian University Entrance Test and also the English Proficiency Index. The tertiary education institutions also lamented the lack of proficiency of undergraduates that does not meet the usual classroom's lecture needs. To achieve the output of marketable human capital, the curriculum used in teaching English in Malaysia is built with Communicative Language Teaching as the underpinning theory. Despite this, teachers are too 
bogged down with clerical workload and the demands of the public standardised tests which made the teaching and learning of speaking skills is given less attention by teachers to be taught in class. However, teachers' role in teaching speaking is imperative, apart from systemic problems, teaching speaking English is also a problem of overcoming anxiety and inhibitions for the students. Teachers play a crucial role in overcoming this problem. This paper has compiled a few creative teaching and innovative teaching approaches in teaching the language of speaking in Malaysian schools, and all these studies stressed on the importance of teachers' in language classroom, especially in the teaching of speaking. The incongruencies between the curriculum and the assessment in Malaysian schools proved to be a stumbling block in the teaching and learning of speaking, however it is up to the teachers to balance the incongruencies and adopt innovative and creative teaching in the hope that Malaysian students will graduate secondary school with good English proficiency. Towards this end, Malaysia will finally realise the aim of creating a marketable human capital who will not only be a sought-after generation but also become highly-productive individuals in the global economy.

\section{References}

Adila, N., Samat, A., Muthu, S., \& Yunus, M. M. (2019). DUBSLINGUISTIC Enhancing English Communication Skills among Malaysian Primary School Pupils. 48-58. https://doi.org/10.4236/ce.2019.101004

Ahmad, M. A. K. A., \& Yunus, M. M. (2019). A Collaborative Learning Intervention Module To Improve Speaking Fluency. International Journal of Scientific \& Technology Research, 8(12), $1834-1838$.

Albury, N. J., \& Khin, K. A. (2016). Malaysia's National Language Policy in International Theoretical Context. Journal of Nusantara Studies, 1(1), 71-84. https://doi.org/10.24200/jonus.vol1iss1pp71-84

Ansari, M. S. (2015). Speaking anxiety in ESL/EFL classrooms: A holistic approach and practical study. International Journal of Educational Investigations, 2(4), 38-46.

Azman, H. (1994). Teaching the KBSM English Language: Towards a Process Oriented Approach. Akademika, 45(2), 23-33.

Azman, H. (2016). Implementation and Challenges of English Language Education Reform in Malaysian Primary Schools. 3L: The Southeast Asian Journal of English Language Studies -, 22(3), 65-78.

Baharun, H., Sidek, H. M., Saazai, N., Saad, M., Muzhafar, M., Idrus, M., ... Ashikin, Z. (2016). The Malaysian Secondary School EFL Speaking Curriculum: A Theoretical Foundation Alignment Analysis. International E-Journal of Advances in Education, 2(6), 465-474.

Chan, H. C., Yunus, M. M., \& Mohamad, M. (2017). ' Who We Are' in Enhancing Rural Students ' English as a Second Language (ESL) Learning. Asian EFL Journal, 2(April), 5-18.

Cheong, K.-C., Hill, C., \& Leong , Y.-C. (2016). Malaysia's Education Policies and the Law of Unintended Consequences . Journal of International and Comparative Education, 5(2), 73-86. https://doi.org/10.14425/jice.2016.5.2.73

Curriculum Development Center. (2003). Huraian Sukatan Pelajaran Bahasa Inggeris Tingkatan 5. In Kementerian Pendidikan Malaysia.

Davies, P., \& Pearse, E. (2000). Success in English Teaching (1st ed.). Oxford: Oxford University Press.

Education First EPI. (2019). EF English Proficiency Index: A Ranking of 100 Countries and Regions by English Skills. Retrieved from https://www.ef.com/wwen/epi/

Hashim, H. U., Yunus, M. M., \& Hashim, H. (2018). 3-minutes pitching with flip grid: An antidote of innovation for speaking anxiety. International Journal of Innovative Technology and Exploring Engineering, 8(7), 1798-1801.

Idris, M., \& Zakaria, M. H. (2016). Gauging ESL Learners' CEFR Ratings on Oral Proficiency in Rater Training. Man in India, 96(6), 1675-1682.

Ismail, H. (2018, October). Merealisasikan Enam Aspirasi Murid: Penghormatan Untuk Wira yang Tidak Didendang. Pendidik, 1-8. $\quad$ Retrieved from https://www.pendidik.com.my/2018/10/30/merialisasi/

Kandasamy, C., \& Habil, H. (2018). Exploring Cooperative Learning Method to Enhance Speaking 
DOI: https://doi.org/10.47405/mjssh.v6i5.786

Skills Among School Students. LSP International Journal, 5(2), 1-16. https://doi.org/10.11113/lspi.v5n2.59

Khan, M. R., Khan, S. R., \& Ahmad, S. (2016). Students' Perceptions about the Importaance of Communication Skills: A Case Study of EFL Learners at Jazan University, Saudi Arabia. International Journal of English Language Education, 4(1), 63-78. https://doi.org/10.5296/ijele.v v4i1.8782

Khan, S. M. (2015). Influence of Speech Anxiety on Oral Communication Skills among ESL/EFL Learners. Advances in Language and Literary Studies, 6(6), 49-53. https://doi.org/10.7575/aiac.alls.v.6n.6p.49

Leong, L., \& Ahmadi, S. M. (2017). An Analysis of Factors Influencing Learners' English Speaking Skill. International Journal of Research in English Education, 2(1), 34-41. https://doi.org/DOI: 10.18869/acadpub.ijree.2.1.34

Lim, P. M. S., Yunus, M. M., \& Mohamad, M. (2016). The Malaysian Education Blueprint 2013 and its effects on English Language teaching in Malaysia The Asian EFL Journal Professional Teaching Articles December 2016 Indonesian International Conference Edition Volume 4 Senior Editors : Paul Robertson and Joh. The Asian EFL Journal, 4(7), 158-171.

Lucanus, A. (2017). Oral Communication Skills Are Important for Students. Retrieved December 18, 2019, from The College Puzzle: A college success blog by Dr. Michael W. Kirst website: https://collegepuzzle.stanford.edu/oral-communication-skills-are-important-for-stude nts/

Mahmoud, M. S., \& Mitkees, H. (2017). Malaysia's Vision 2020 and the Role of leadership in Economic Development. Asian Social Science, 13(8), 49. https://doi.org/10.5539/ass.v13n8p49

Majid, N., Ahmad, R. R., Mamat, N. J. Z., Rambely, A. S., Muda, N., Jaaman, S. H., ... Mahmood Rafee, N. (2012). Transformation of Language in Teaching and Learning Policy. Procedia Social and Behavioral Sciences, 59, 685-691. https://doi.org/10.1016/j.sbspro.2012.09.331

Majlis Peperiksaan Malaysia. (2017). Laporan Peperiksaan MUET 2017. Retrieved from http://portal.mpm.edu.my/laporan-peperiksaan-stpm-dan-muet-tahun-2017

Mangaleswaran, S., \& Aziz, A. A. (2019). The Impact of the Implementation of CLT On Students' Speaking Skills. International Journal of Scientific and Research Publications (IJSRP), 9(4), p8814. https://doi.org/10.29322/ijsrp.9.04.2019.p8814

Ministry Of Education. (2002). Pengendalian Ujian Lisan Berasaskan Sekolah.

Ministry Of Education. (2013). Malaysia Education Blueprint 2013 - 2025. In Ministry of Education. https://doi.org/10.1016/j.tate.2010.08.007

Ministry Of Education. (2015). English Language Education Reform in Malaysia: The Roadmap 2015-2025.

Ministry Of Education. (2017). Dokumen Standard Kurikulum dan Pentaksiran Bahasa Inggeris Kurikulum Standard Sekolah Menengah (Tingkatan 1) (1st ed.). Putrajaya: Kementerian Pendidikan Malaysia.

Ministry Of Education. (2018). Dokumen Standard Kurikulum dan Pentaksiran Bahasa Inggeris Kurikulum Standard Sekolah Menengah (Tingkatan 4) (1st ed.). Putrajaya: Kementerian Pendidikan Malaysia.

Misbah, N. H., Mohamad, M., Yunus, M.M., \& Ya'acob, A. (2017). Identifying the Factors Contributing to Students' Difficulties in the English Language Learning. Creative Education, (8), 1999-2008. https://doi.org/10.4236/ce.2017.813136

Mohamad Uri, N. F., \& Abd Aziz, M. S. (2018). Implementation of CEFR in Malaysia: Teachers ' awareness and the Challenges. 3L: The Southeast Asian Journal of English Language Studies -, 24(3), 168-183. https://doi.org/http://doi.org/10.17576/3L-2018-2403-13

Moon, W., \& Park, O. (2019). Factors affecting English Language Learning Motivation of Korean Freshmen and their General Characteristics. International Journal of Recent Technology and Engineering, 8(2S6), 22-26. https://doi.org/10.35940/ijrte.b1005.0782s619

Neill, M. O., \& Chapman, A. (2015). Globalisation, Internationalisation and English Language: Studies of Education in Singapore, Malaysia and Australia. Education Research and Perspective: An International Journal, 42, 1-24.

Nguyen, H. T., \& Tran, N. M. (2015). Factors Affecting Students' Speaking Performance at Le Thanh Hien High School. Asian Journal of Educaitonal Research, 3(2), 8-23.

Nunan, D. (1991). Language Teaching Methodology: A Textbook for Teachers (1st ed.). Prentice Hall. Nunan, D., \& Bailey, K. (2003). Practical English Language Teaching. In D. Nunan (Ed.), McGraw- 
Hill (Internatio). Singapore: McGraw-Hill.

Rahman, M. S. (2016). The Advantages and Disadvantages of Using Qualitative and Quantitative Approaches and Methods in Language "Testing and Assessment" Research: A Literature Review. Journal of Education and Learning, 6(1), 102. https://doi.org/10.5539/jel.v6n1p102

Ramamuruthy, V. (2019). The Effects of Task-based Approach on Speaking Anxiety among ESL Low Proficiency Diploma Students. Universal Journal of Educational Research, 7(6), 1363-1375. https://doi.org/10.13189/ujer.2019.070604

Rao, S. S. (2009). Globalisation, Affirmative Action and Higher Education Reforms in Malaysia: A Tightrope Walk between Equality and Excellence. The Asian Scholar, 5, 1-26.

Rashid, R. A. B., Rahman, S. B. A., \& Yunus, K. (2017). Reforms in the policy of English language teaching in Malaysia. Policy Futures in Education, 15(1), 100-112. https://doi.org/10.1177/1478210316679069

Roever, C., \& McNamara, T. (2006). Language Testing: The Social Dimension. Retrieved from https://books.google.com.my/books?id=XrOE14OdUwEC\&printsec $=$ frontcover\&source=gbs_g e_summary_r\&cad $=0 \# \mathrm{v}=$ onepage $\& \mathrm{q} \& \mathrm{f}=$ false

Thirusanku, J., \& Yunus, M. M. (2017). Status of English in Malaysia. Asian Social Science, 10(14), 254-260. https://doi.org/10.5539/ass.v10n14p254

Toyama, M., \& Mori, K. (2017). Reducing Student Anxiety: The Effects of Collaborative Learning through Computer Conferencing. International Journal of Information and Education Technology, 7(12), 10-13. https://doi.org/10.18178/ijiet.2017.7.12.993

University of Cambridge. (2011). Using the CEFR: Principal of Good Practice. Retrieved from http://www.cambridgeenglish.org/images/126011-using-cefr-principles-of-good-practice.pdf

Wan, C. Da, Sirat, M., \& Razak, D. A. (2018). Education in Malaysia Towards a Developed Nation. In Economics Working Paper (No. 2018-4).

Wong, C. W. (2019, December 15). Teaching with a purpose. The Star Online. Retrieved from https://www.thestar.com.my/opinion/columnists/on-the-beat/2019/12/15/teaching-with-apurpose?fbclid=IwAR2qkBs7lvf0TYd0vzmZ4tTrkUm7PScGfKnccqFaOwZWDO1i2bRPFLTvZqE

Yaakob, M. F. M., Musa, M. R., Habibi, A., \& Othman, R. (2019). Strategic Management and Strategic Planning in School: Is It Worth for Teachers? Academy of Strategic Management Journal, (3), 1-6. Retrieved from https://www.researchgate.net/publication/333662860\%0ASTRATEGIC

Yang, L. F., \& Ahmad Ishak, M. S. (2012). Framing controversy over language policy in Malaysia: the coverage of PPSMI reversal (teaching of mathematics and science in English ) by Malaysian newspapers. Asian Journal of Communication, 22(5), 449-473. https://doi.org/http://dx.doi.org/10.1080/01292986.2012.701312

Zaki, M. H. ., Yunus, M. M., \& Hashim, H. (2017). The Use of Audio Visual Aids in Developing Pupil's Speaking Skills: Malaysian Context. Asian Social Science Journal, 4, 165-172. 